\title{
Enhanced volatile fatty acid production from sago hampas by Clostridium beijerinckii SR1 for bioelectricity generation using microbial fuel cells
}

\begin{abstract}
Sago hampas is a starch-based biomass from sago processing industries consisted of 58\% remaining starch. This study has demonstrated the bioconversion of sago hampas to volatile fatty acids (VFAs) by Clostridium beijerinckii SR1 via anaerobic digestion. Higher total VFAs were obtained from sago hampas $(5.04 \mathrm{~g} / \mathrm{L}$ and $0.287 \mathrm{~g} / \mathrm{g})$ as compared to commercial starch $(5.94 \mathrm{~g} / \mathrm{L}$ and $0.318 \mathrm{~g} / \mathrm{g}$ ). The physical factors have been investigated for the enhancement of VFAs production using onefactor-at-a-time (OFAT). The optimum condition; 3\% substrate concentration, $3 \mathrm{~g} / \mathrm{L}$ of yeast extract concentration and $2 \mathrm{~g} / \mathrm{L}$ of ammonium nitrate enhanced the production of VFAs by $52.6 \%$, resulted the total VFAs produced is $7.69 \mathrm{~g} / \mathrm{L}$ with the VFAs yield of $0.451 \mathrm{~g} / \mathrm{g}$. VFAs hydrolysate produced successfully generated $273.4 \mathrm{mV}$ of open voltage circuit and $61.5 \mathrm{~mW} / \mathrm{m} 2$ of power density in microbial fuel cells. It was suggested that sago hampas provide as an alternative carbon feedstock for bioelectricity generation.
\end{abstract}

Keyword: Sago hampas; Clostridium beijerinckii SR1; Volatile fatty acids; Microbial fuel cells; Bioelectricity generation 